\title{
Influence of Rural Electrification for Development of Quality of Life:A Preliminary Investigation
}

\author{
Anand Vijay Satpute ${ }^{1^{*}}$, E. Vijay Kumar ${ }^{1}$ \\ ${ }^{1}$ Department of Electrical Engineering \\ SarvepalliRadhakrishnan University, MP-462026, Bhopal-India
}

D.O.I- DOI: $10.51201 / J U S S T / 12467$

http://doi.org/10.51201/Jusst12467

\begin{abstract}
Evaluating the importance of electricity in one's life is the key to success. The present article brings light on the role of electrification not only for meeting the mere utilities but also on the enhancement of capability of rural people of India. Electrification can play a vital role in accelerating the quality of life of the people. Two villages in Nashik district within the state of Maharashtra have been taken for the qualitative evaluation. The study uncovered the fact that, electricity may be treated as a climacteric means to enhance people's decisions and opportunities within the trailing of quality lives. In addition to this, it also uncovered that the advantages of electricity don't seem to be uniformly benefitted all the families within the villages taken for the survey. Government policies for rural electrification should be backpedalled and the conventional definition of electrification in rural areas must be integrated with the scope of usage of solar photovoltaic. This article additionally suggests that the policies are to be made to increase easy access of electricity by rural people for adding values in their quality of life and enhancing their capabilities in present socio-political environment.
\end{abstract}

Keyword: Electrification and Quality of Life, Rural India, Safety, Society, Lifestyle

\section{Introduction}

Electricity is one of the most important pillars of civilisation. With the advent of science and technology demand of electrification increases day by day. In every corner of society and in many household appliances blessings of electrification is highly needed. Communication, information technology, lighting, air conditioner, refrigerator, food preservation, entertainment services and many other technologies are dependent solely on the supply of electricity.However, all the advantages brought about by electrification are to fulfil people's daily needs. Utilisation of electric appliances does not provide detail understanding of the role of electrification in development of quality of life. A rigorous analysis is being demanded to establish the actual role of electrification in developing capability and quality of life of the rural people of India. 
This present analysis augmented the conception of evaluation of electric services from a point of view which highlighted capability development instead of highlighting meagre advantages it offers to rural people [1]. It will be interesting to assess the function of rural electrification from a newer point of view which takes into account of capability development of people through electrification [2-3].Ease of accessing residential electricity in India has been ameliorating since the year of 2001. The data obtained from census report of India depictedin table 1 reveals that between the year of 2001 and 2011, India electrified more than 50 million homes which include rural and urban households(HHs)[4-5].

Table 1.Status ofHHs electrified between 2001 and 2011, India [4-5].

\begin{tabular}{lcc}
\hline Description & $\mathbf{2 0 0 1}$ & $\mathbf{2 0 1 1}$ \\
\hline Total numbers of HHs & $19,19,63,935$ & $24,67,40,228$ \\
Total numbers ofHHs electrified & $10,72,09,054$ & $16,59,35,192$ \\
Percentage & 55.8 & 67.25 \\
Total numbers ofrural HHs & $13,82,71,559$ & $16,78,74,291$ \\
Total numbers ofrural HHs electrified & $6,01,80,658$ & $9,28,45,936$ \\
Percentage & 43.5 & 55.31 \\
Total numbers ofurban HHs & $5,36,92,376$ & $8,08,88,766$ \\
Total numbers ofurban HHs electrified & $4,70,28,369$ & $7,30,89,256$ \\
Percentage & 87.6 & 92.68 \\
\hline
\end{tabular}

Besides, table1 conjointly shows for a period of 10 years, the share of household electricity for lighting enlarged from 58\% to $67.25 \%$ and it may have increased beyond that by the end of March 2020 . Although the aim of 'National Electricity Policy 2005' to achieve full electrification in all houses is still embryonic.Almost 81 million households don't have access of electricity and out of which 93\% households come under bucolic areas. However per capita electricity consumption has increased from $914.41 \mathrm{Kwh}$ to $1122 \mathrm{Kwh}$ since 2012.India's headway in rural electrification is credited because of strategically launching of national program namely Rajiv Gandhi GrameenVidyutikaranYojana(RGGVY) in 2005[6],later colligated under DeendayalUpadhyaya Gram JyotiYojana(DDUGJY) in 2015 [6].PradhanMantriSahajBijliGharYojana also known as Saubhagya launched at $25^{\text {th }}$ September, 2017 to provide free electricity connections to all $\mathrm{HHs}$ both in rural and urban regions [7].A village can be privileged for electrification whether its inhabitants are of 100 or more by this program. The government says that there has been a village taken into account that at least $10 \%$ have power connections irrespective of the quality of electrification [8]. It highlights when its 1 home from 100 families is electrified a village is known as an electrified village There is a shift in 
government definition from the preceding that thought of an electrified village is if a village includes electrified pumps used for irrigation purpose. Before 1997, government's focus was on the development of agriculture using benefits of electricity. At this stage economic benefit of electricity was rest on its use in the field of agriculture. There is an increase of demand of energy per capita with population as shown in figure1.From this figure it is evident that there is a need to increase the rural electrification in the villages[9].Table 2 givesan overview of funding under DDUGJY scheme[10].

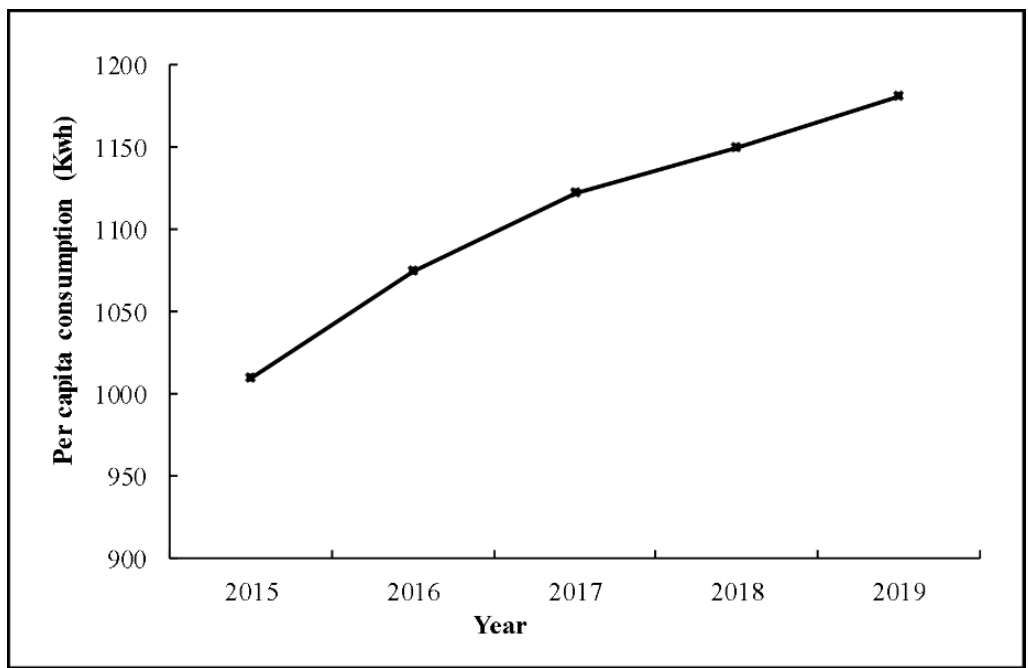

Fig.1Per capita electricity consumption in last 5 years [9].

Table 2. Funding mechanism of DDUGJY [10].

\begin{tabular}{|c|c|c|c|}
\hline \multirow{2}{*}{ Agency } & \multirow{2}{*}{ Nature of support } & \multicolumn{2}{|c|}{$\begin{array}{c}\text { Quantum of support } \\
\text { (Percentage of project cost) }\end{array}$} \\
\hline & & $\begin{array}{l}\text { Other than Special } \\
\text { Category States }\end{array}$ & $\begin{array}{l}\text { Special Category } \\
\text { States \# }\end{array}$ \\
\hline Government of India (GOI) & Grant & 60 & 85 \\
\hline $\begin{array}{l}\text { State distribution company } \\
\text { contribution }\end{array}$ & Own Fund & 10 & 5 \\
\hline $\begin{array}{l}\text { Lender (Financial Institutions/ } \\
\text { Banks) }\end{array}$ & Loan & 30 & 10 \\
\hline $\begin{array}{l}\text { Additional Grant from GOI on } \\
\text { achievement of prescribed } \\
\text { milestones }\end{array}$ & Grant & \begin{tabular}{|l|}
$50 \%$ of total loan \\
component $(30 \%)$ i.e. \\
$15 \%$
\end{tabular} & $\begin{array}{l}50 \% \text { of total loan } \\
\text { component }(10 \%) \\
\text { i.e. } 5 \%\end{array}$ \\
\hline $\begin{array}{l}\text { Maximum Grant by GOI (including } \\
\text { additional grant on achievement of } \\
\text { prescribed milestones) }\end{array}$ & Grant & $75 \%$ & $90 \%$ \\
\hline
\end{tabular}

\# (All states of North-East India including Jammu \&Kashmir, Himachal Pradesh, Uttarakhand and Sikkim)

The present draft of the National Electricity Plan set up in 2016 predictsaccess to electricity by 2019 [11]. It shows government's commitment towards achieving the $7^{\text {th }}$ Sustainable Development Goals (SDGs). 
SDGs had the vision to bring electricity to all households by 2010 and to supply sufficient power for achieving the need of electricity of every HHs within the year of 2012[12].To the disappointment, it underperforms to attainelectrification goalsand recommends that its on-going SDGdriven targetsare more challenging and ambitious.India'sattempt to achieve $100 \%$ electricity access may fail, if it refrains from understanding the necessity electricity among poor and minority in rural India [13].According toa study made, it states that financially weaker sections have lesser opportunity to accesselectricity when they are compared to financially stronger sections and therefore it suggested that the government policy are to be made more dynamic and innovative to lay emphasis on the electrification of poor households and villages to impart constructive and positive changes in quality of life of people in rural regions so that these people can be made more efficient to contribute towards country's financial up gradation. The presentsurvey intended to: 1) assess the function of electrification rural Indiaand its impact on people's lifestyles; 2) evaluation of improvements of quality of life and capability by consumption of power by citing qualitative evidences; 3) advocate suggestions to reduce the drawbacks of electrification coverage in rural India.This survey was brought about taking 2 villagesat Nashik district comes under Maharashtra from August 2018 to the end of February 2019. Major reason for the choice of selection of these two villages is that most of the families belong to the Scheduled Caste (SC), Scheduled Tribe (ST), Other Backward Caste (OBC) and Economically Backward Class (EBC). According to Government of India all these sections may be treated as socially, economically and politically weaker sections [14].The study was made by using (i) Case study approach, (ii) Data collection, (iii) Comprehensive one to one interview; (iv) Observe the participant. The villages which make them suitable for the study is that all the houses under the scheme were electrified.

\section{Theory framing}

The normative frameworkof Capability Approach (CA) is pioneered and expanded by many in the past [1-2]. A crucialproposition of the CA is that judgement of standard of life of a person should not be on the basis of amount of resource he has consumed or the amount of resource he has occupied.The new theoretical framework of CA is all about wellbeing, development and justice. There has been a new traditionin conceptualizing energy as a tool to evaluate its efficacy to improve well-being by means of CA. To achieve values in life energy can emerge as a vital contributor which can play an important role to enhance quality of [15]. Capability can be distinguished as primary and secondary where energy is subjected as an unavoidable component.According to Amartya Sen, basic capabilities can be regarded as "the ability to satisfy certain elementary and crucially important functioning up to certain levels". Basic capabilities can be of different types including maintenance of good health, keeping away from premature death, engaging in social interaction are the ultimate concerns of an individual or a household. Secondary capabilities are of many 
types likerunning irrigation pumps and using appliances [1].It has been acknowledged thatthough pivotal role of energy services in enhancing values in quality life but it does not seem to announce any specified services. Further the discussion continues which capabilities are essential and which are not. For this purpose, in this work, two methods are presented. In the first method, approach is to take central capabilities offered and then assess the energy services role.And whereas in second, one can develop capabilities list which involves people from sectors range, for instance, users, policy-makers and energy suppliers and distributors [16-17].

Researchers have adopted the energy poverty definition to rate the energy poverty scenario in India $[1,18]$. The analysis has estimated the energy poverty degree, as per survey statistical analysis data in India, discovering its impacts and is prevalent in rural regions. They assert that its test must be achieved with a framework like the CA, which will assist enough comprehensive designing action plans to tackle power requirement and contribute to enhancing the lives of men and women and affirm that the character of energy poverty.This analysis is established on the scholar's work, which will accept that energy providers are having a role in enhancing lifestyle of people and have attempted to conceptualize energy providers utilizing the CA. The research is concerned less with how happy or satisfied a person is after having power. It lessens the concept of measuring the amount of energy consumption in enhancing the quality of your daily life to evaluate its involvement and claims. It centres on electricity in assisting individuals to comprehend capacities as a source. The present paper reveals that electricity has brought about positive changes to achieve capabilities in these two villages in India [1]. It does so by using a qualitative and small approach to analyse that rural electrification have contributed to enhance their lives.

\section{Research Methodology}

Maharashtra is based on the western peninsular region of India. Maharashtra is India's third-largest state in size and the second ranked state in population, as per to the Census in 2011[4-5]. Figure 2 shows Nashik, which is a district in Maharashtra for which the study has been done. According to Census in 2011, the district has more than one million populations, \& $76 \%$ houses are electrified. Given Table 3 illustrates the substantial progress in rural electrification that happened in Nashik [5]. In 2011, the district was having literate population more than $67 \%$. The top two income generating choices were agriculture \& animal husbandry which contribute to economy of the district. Beyond this, $62 \%$ of rural households were electrified that's $20 \%$ less compared to urban family electrification ${ }^{[5]}$. The duration for research fieldwork was from September 2018 to March 2019for the two villages as shown in figure 2, Jategaon \& Talegaon. This research got help by Third year and Fourth year students of Electrical Engineering Department, Sandip Institute of 
Engineering and Research Centre, Nashik. The initial part includes overall introduction \& overview with families and members of those villages. Consents were taken to participate in the research and this point aimed to tell about purpose of the project. Where families, which were prepared to take part, were tentatively identified, it was in this stage, the next phase involved data collection for the research.

Table 3.Status of HHs electrified in 2011, Nashik [5].

\begin{tabular}{lc}
\hline Description & $\mathbf{2 0 1 1}$ \\
\hline Total number of HHs & $11,80,293$ \\
Total number of HHs electrified & $9,04,710$ \\
Percentage & 76.65 \\
Total number of rural HHs & $6,61,977$ \\
Total number of rural HHs electrified & $4,11,152$ \\
Percentage & 62.11 \\
Total number of urban HHs & $5,18,316$ \\
Total number of urban HHs electrified & $4,93,558$ \\
Percentage & 95.22 \\
\hline
\end{tabular}

Detailed interviews and observation of participantswere used for collecting dataas creating a qualitative understanding was the aim of this study. The interviewing version is helpful in understanding values and experience in a certain social context [19]. Participation monitoring allows investigators to understandthe daily life of study participants outside interactions [20]. 80 interviews were conducted in every village, after which there was no hope for emerging significant information. 

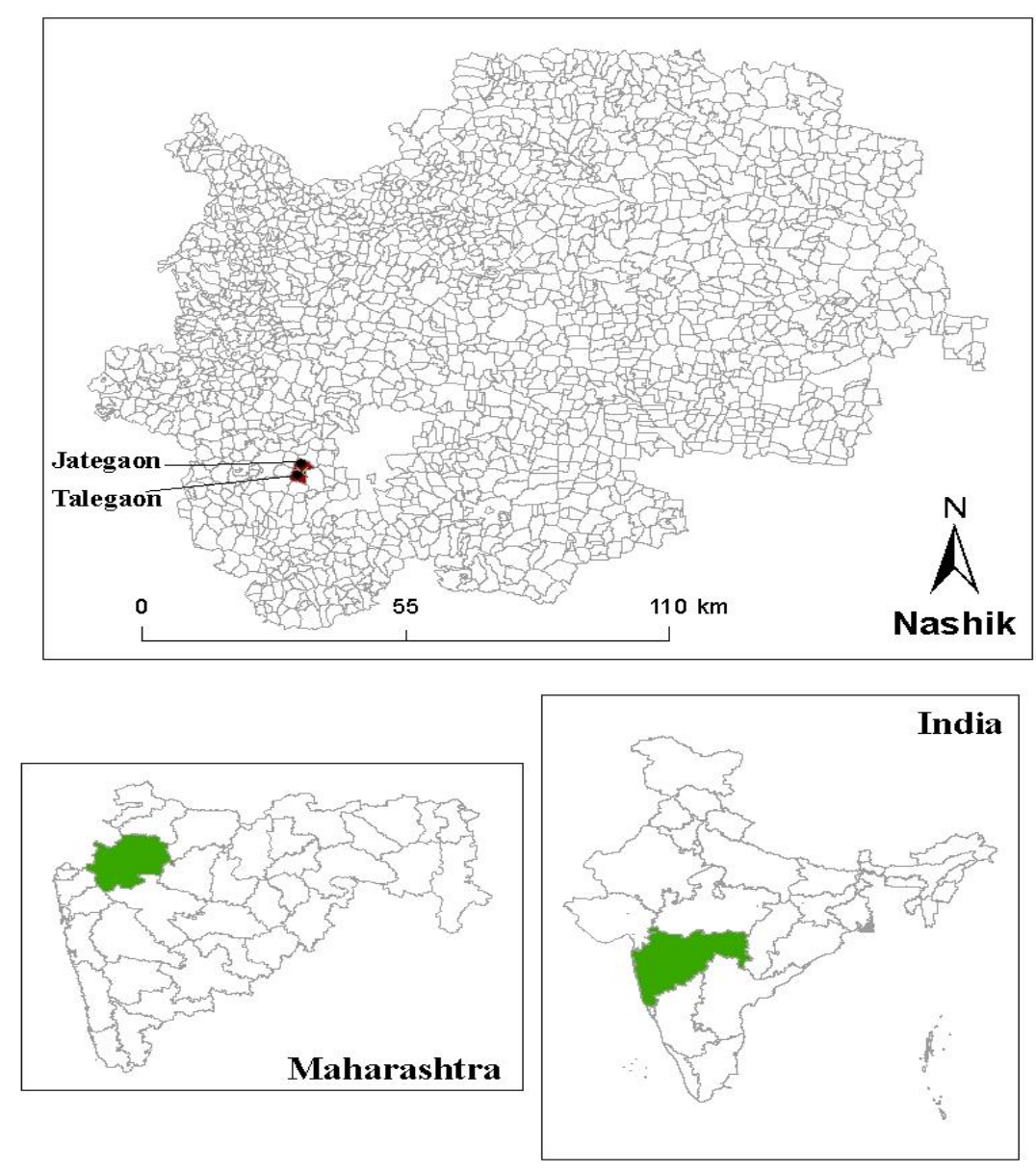

Fig. 2 Map for the study area.

A total of 209 families in Jategaon, 192 families in Talegaon gave interview using interview protocol \& during the stay in the villages, causal interaction was with people irrespective of gender biasness.A journal was maintained by researcher to document the details from interaction. The protocol for interview included questions regarding well-being of people along with also the choices and opportunities expansions connected with family electrification. The interviews lasted about an hour, which were not audio recorded. The cooperation between researcher and interview participants was built greatly as the lodging was in the same village, which allowed them to celebrate livelihood options, community preferences and daily chores. During the survey which lasted for more than 5 months, most of the villagers have access to electricity but the government information on new schemes does not reached to them. 


\section{Results}

There were 292 houses and 985 inhabitants in Jategoan whereas Talegaon has 192 houses with 864 inhabitants. Classification of village houses can be done into two classes based on construction materials utilized, which is called pakka, made from concrete, bricks, steel, and tin roof, and Kutcha, made from timber, mud, thatch and alternative substances having low quality. Both the villages have families belong to Above Poverty Level (APL) and Below Poverty Level (BPL) as categorized by the GoI. The roads, in the villages were unpaved and the market places were more than 8 and $6 \mathrm{~km}$ away from Jategaon and Talegaon respectively. Both villages got electricity in 2000 and each home got connected to it. The observed usages of electricity were charging cell phones and emergency light, watching TV and pumping ground water for irrigation. Figure 3 shows key electric appliances used by families who gave interview. When interviewee reactions were placed within the $\mathrm{CA}$, the observation has led to enlarge capacities to realize many valued functioning like improved security, engaging in recreational activities, greater resilience to changing climate, as well as enhanced health.

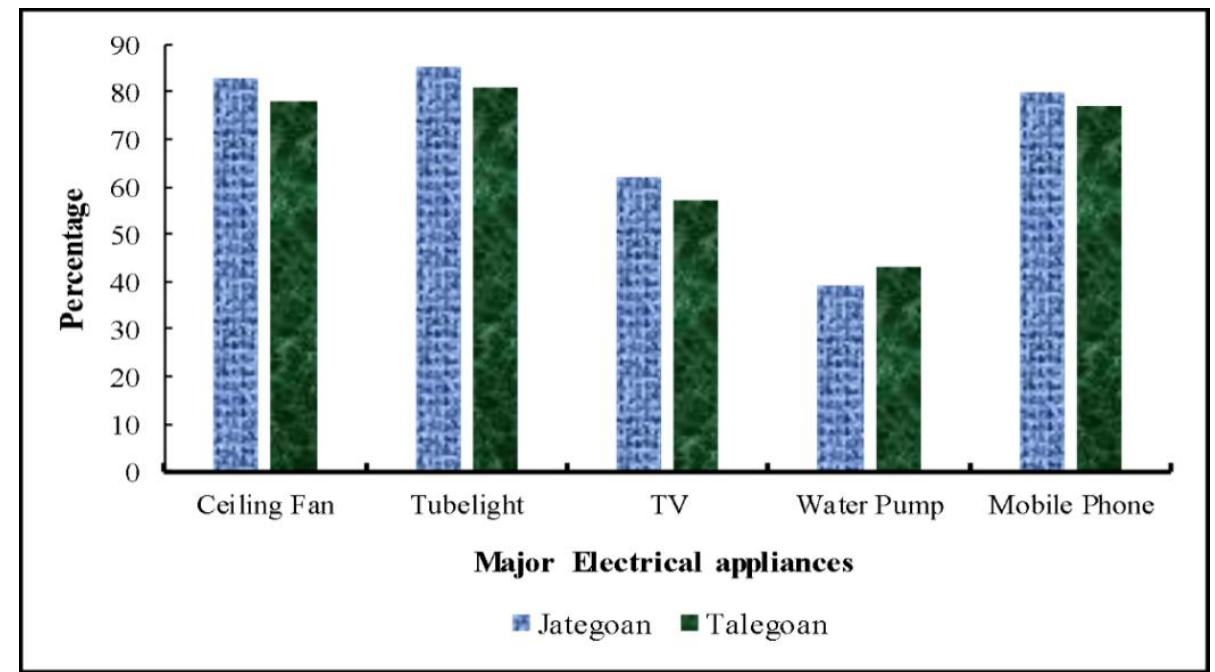

Fig.3 Major Electrical appliances usage [Field Work].

During the interaction with the villagers it came to light that they are deprived of most of the beneficial schemes which can champion the cause of government effort to bring all people above poverty level. News and information regarding the improvement schemes are able to reach to common man of the village as most of them are not having TV and radio at their homes and mobile too is not the multimedia one to access news on it. Total 145 families, 76 in Jategoan and 69 in Talegaon which belongs to BPL category have bare minimum electrical appliance, fan and tube light at their household. 


\subsection{Improved safekeeping}

The role of electricity in enabling added security against possible physical threats and violence was an important achievement reported by research participants. Being specific, household and street lighting offers opportunities to protect livestock from wild animals and enhance activities after dark. As $99 \%$ villagers mentioned, livestock is a vital income generating choice, and shedding livestock also contributes to dropping earnings. People have felt a greater sense of security after village electrification as reported by interviewees. As per stated by a couple in an interview, they keep the lights ON in their livestock shed on all night. (Jategaon, Interview \#1).The street lights have reportedly improved the freedom in the study villages of women. Mobility is an intrinsic in addition to instrumental capability, especially for women whose motions are generally restricted due to physical and social factors [15]. In an informal interaction with some women's in Talegaon, they told that they were worried in the absence of street lights, it had been hard for them to walk around the village following the sunset. They stated, it isn't an issue anymore. What's more, they stated that after lights have been installed, they might go to bring drinking water from a faucet after dark which needs 5 minute walk from the village and that otherwise could have been dangerous and difficult. As reported by the researcher, women were not hesitant to come out in the evening for chit-chat after the installation of street lights. On a certain occasions, interviews were taken in the day after $6 \mathrm{pm}$ because individuals were busy during the daytime. It had been observed that interviewees seemed pleased since they had sufficient lights to sponsor the research workers in their homes after dark. Children were observed playing even though the researcher carried out interviews and adults doing work under lights during the evening hours.

\subsection{Recreational activities}

One of the fundamental capability proposed is to enjoy recreational activities [17]. The necessary means to attain basic areas of well-being are identifying leisure tasks that enable relaxation and creativity [15]. The collected data discovered in Fig. 2, shows the research villages, nearly $4 / 5^{\text {th }}$ of the interviewed families possessed a Ceiling fan and Tube-light and $3 / 5^{\text {th }}$ owned TV. They have been among the essential appliances after electrification as reported by interviewees. Interviewees mentioned that they use TV for various purpose which includes relaxing after hectic day, keep their children at home in the dark, getting worldwide information. As stated by an interview: Radio and TV are after a day for time departure and comfort. (Talegaon, Interview \#1) In a meeting, a married couple explained: TV provides a fantastic incentive for kids to beat home rather than drifting from the village after dark. In a casual conversation with some of the women, who explained how much they prefer to see TV shows. As per them, watching TV and listening to the radio is part of their entertainment. They stated that every single day after hard work, spending time viewing TV shows is a way. They shared their work, accomplishments and failures while watching TV. 


\subsection{Increased flexibility to changing climate}

Together with the conceptualization of the CA, that living in natural environment is a critical capacity for achievement about health. For the villages, power has led some households to adapt themselves towards altering climates. ragi, tomatoes, onion, and grapes are their major crops and every family interviewed were the farmers belong to a different section. Table 3 below shows a harvest of crops with rain-water and bore wells with electrical water pumps. People having household motor pumps have started to cultivate off-season ragi, onions and tomatoes by using groundwater making more income than individuals who didn't have pumps. A couple of households installed foreclosed wells, and individuals who have it, cultivate great revenue lending fruits such as grapes. If there is no rain, still agriculture is the main job. This season, tomatoes was a failure and was due to delayed rain. (Jategaon, Interview \#2) In reaction to agricultural reverses, one-fourth of these study participants either had set up bore wells or water pumps installed in adjoining lake to extract water for irrigation to withstand changing pattern of rain. Three of the participants told that they were planning to dig bore wells for the same function. As per the reports, motivations behind using electric water pump for irrigation is govt. providing subsidy for it. Interviewees expressed their dissatisfaction, they felt about the reducing and irregular rain patterns in the region, which affected crops. (Talegaon, Interview \#2) Though usage of groundwater provides opportunities to some households to enlarge the time for growing valuable crops, a more number of families have to be rely on rain. As mentioned, installing a bore well is expensive, and is beyond budget for some families. For example, a family need to invest more than 50,000 rupees to dig a bore well and need to give additional charges to local electricity board. As agricultural field is far away from the road, it requires erecting seven poles to expand the power connection to their area. The authorities provided four poles and needed to manage an additional three poles.

\section{Discussion}

The observations suggest that electricity access is pivotal in expanding the study participants chances and decisions in the study of the villages. Fig. 3 screens electricity contributions made in attaining basic \& secondary abilities. The evidence provided in the research paper is that critical source for families is power in the study sites not by inquiring who satisfied the power users were or consumed more of this source. It did so by asking interviewees in assisting them to achieve exactly what they wanted to do with the source available. Lighting has enhanced villager's safety and allowed each of the interviewed villagers to sense security against any threat. Research participants pointed out that their lands are far much better sheltered today than before and putting lights has deterred wild animals. Street lights have enhanced liberty of freedom 
and have reduced the possibility of violence. Most of the women interviewees stressed that before the electrification of the village and after the evening they feel fear to come from their homes while after the street lighting situation is changed and now they can come out from their houses after dinner for a small gathering. Electricity have improved development of involvement of people Table 4 depicts crop cultivation pattern in Talegaon which is quite the same for Talegaon also [Field Work]. Not all the farmers have the liberty of bore-well in their farm as most of them are dependent on seasonal rains and lake water and rest of time work as farm labour. Research participants mentioned that they watch TV to entertain themselves and no to waste time and unwind after hard day of labour and availability of information. Resources provide way to enhance skills of people, but it has to admit that people have different capacity to convert resource into usable form [15].Not all households can convert resource to usable form. For example, due to legislative and financial limitations, most households could not use an electric pump.

Table 4.Crops cultivating pattern in Jategaon [Field Work].

\begin{tabular}{|c|c|c|c|c|c|c|c|c|c|c|c|}
\hline Crops & \begin{tabular}{|l|} 
Irrigation \\
\end{tabular} & Jan & Feb & Mar & Apr & \begin{tabular}{|l|l|} 
May & June \\
\end{tabular} & Jul & Aug & \begin{tabular}{|l|l|} 
Sept & Oct \\
\end{tabular} & Nov & Dec \\
\hline \multirow{2}{*}{ Grape } & Rain & & & & & & & & & & \\
\hline & Borewell & & & & & & & & & & \\
\hline \multirow{2}{*}{ Tomatoes } & Rain & & & & & & & & & & \\
\hline & \begin{tabular}{|l|} 
Borewell \\
\end{tabular} & & & & & & & & & & \\
\hline \multirow{2}{*}{ Ragi } & Rain & & & & & & & & & & \\
\hline & Borewell & & & & & & & & & & \\
\hline \multirow{2}{*}{ Onion } & Rain & & & & & & & & & & \\
\hline & Borewell & & & & & & & & & & \\
\hline
\end{tabular}

Furthermore, there is no TV in every home and no one appreciated fundamental capabilities associated with amusement. Hence this research paper argues that only access to electricity will not lead to equal opportunities for all. Paper suggests that rural electrification coverage, along with new houses electrification, should provide ways to promote use of electricity for various functions which might have significant participation in life of people.

Though RGGVY provides free electricity links to low-income families, power usage is not at all free of cost and need to pay monthly power bill might be difficult task for all those families [13]. As per them, this may lead to two consequences: viz. poor families can't think of usage of electricity for free and sometimes they can't even use electricity though there houses are electrified. The study evidences next implication. This study strongly objects agenda of GoI to electrify certain number of houses and to announce it like rural electrification, but it should be to electrify every house in rural area properly $\&$ provide them political $\&$ social aids to improve their standard of living. The paper asserts that the success of this scheme is not simply getting houses, but also providing the choices and chances of people to attain proper living standards by using electricity. In addition, this paper is novel in so many aspects: one of them lies in its strategy used for study. 
Figure 4 enlist electricity role had played in providing its capabilities. Use of qualitative strategy has allowed a comprehensive study of life of people and ability to distinguish between what are the potential resources (opportunities) and they actually have achieved. This paper has recorded precisely how the electricity may enrich chances in detail, although a strategic survey may have lacked this specific detail \& might have concentrated more on functioning as opposed to capabilities.

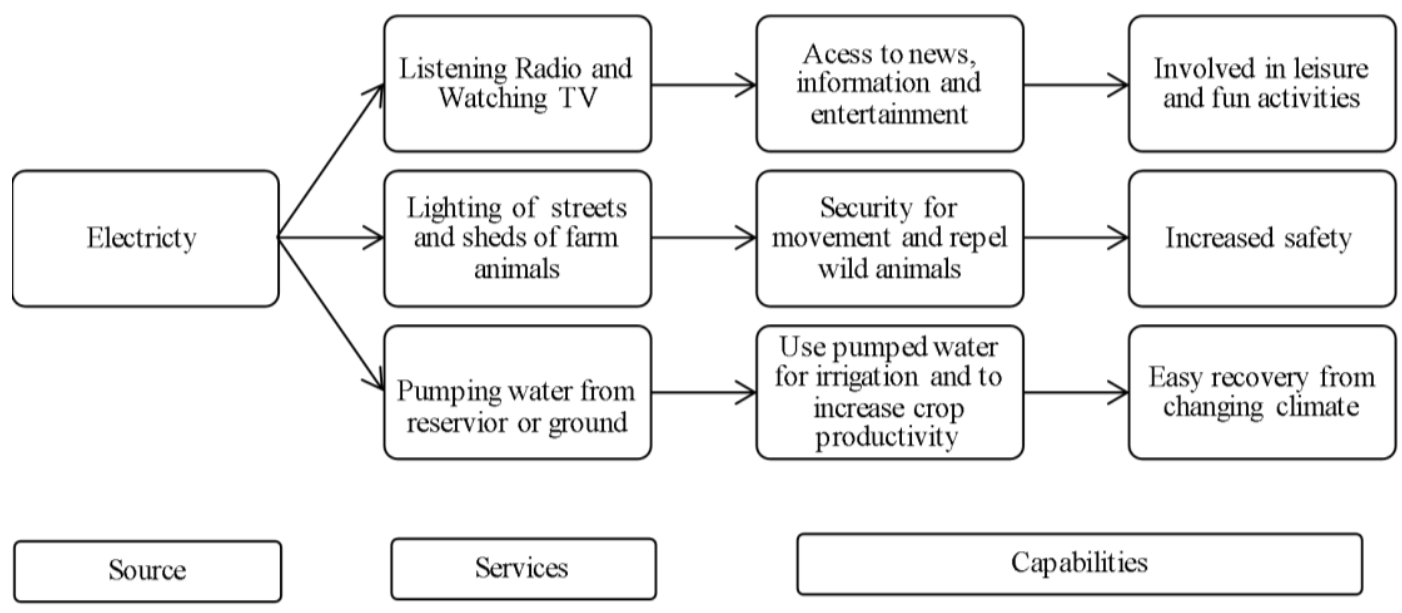

\section{Conclusion}

Fig.4Role of electricity [Field Work].

This paper rejects the concept of having count for total number of houses and understanding the amount of energy utilized by consumers to find out benefits rural electrification. It sets the possibilities that power access allows families to improve their life quality as the impact of rural electrification. The observations imply, power is one of the crucial sources which contribute to expand abilities of people to pursue but this lack in some homes from the village. Access to power has not boosted the chances of opportunities to all the villagers. With the help of those findings, this research puts forward two coverage guidelines. This study has determined that power is not the end, but it can give lots of opportunities to boost essential capability. This study came to conclusion that, GoI is more interested in announcing electrification for the villages than providing actual opportunities to improve standard of life for them and promoting use of a standalone solar photovoltaic application.

Secondly, the paper implies that the policy for rural electrification has to promote both access to electricity as well as enhance political \& social preferences which might help individuals to convert power access into precious capacities, especially to weaker segments of society. Rural electrification schemes such as RGGVY, DDUGJY and Saubhagya which can champion the cause of government effort to bring all people above poverty level by giving easiest access to electricity and increase the productivity. These recommendations derive from the results of research conducted in two villages in Nashik district, Maharashtra, India. 
Therefore, the analysis could have limitations about its scale and representativeness. The approach enabled a gateway to comprehend that the enhancement of people's capacities with regard to rural electrification in a wonderful depth, which a qualitative strategy may have neglected to detect.

\section{Acknowledgement:}

One of the authors, Anand Vijay Satpute, gracefully acknowledges to Dr. D. K. Rajak, who is an Assistant Professor of Department of Mechanical Engineering, SITRC in Nashik for evaluating this manuscript and give valuable comments and suggestions, which help this study to be enriched and improved.

\section{References}

[1] Pachauri, Shonali, et al. "On measuring energy poverty in Indian households." World development 32.12 (2004): 2083-2104.

[2] Day, Rosie, Gordon Walker, and Neil Simcock. "Conceptualising energy use and energy poverty using a capabilities framework." Energy Policy 93 (2016): 255-264.

[3] Sen, Amartya. "Capabilities and Resources." Political Philosophy in the Twenty-First Century. Routledge, 2018. 119-131.

[4] Available online: http://censusindia.gov.in/2011census/Hlo-series/HH11.html. [Access date15-102020]

[5] Available online:

http://censusindia.gov.in/2011census/dchb/DCHB_A/27/2720_PART_A_DCHB_NASHIK.pdf.[Acces $s$ date15-10-2020]

[6] Available online: http://pib.nic.in/newsite/PrintRelease.aspx?relid=123595. [Access date15-102020]

[7] Available online: https://powermin.nic.in/en/content/saubhagya. [Access date15-10-2020]

[8] Oda, Hisaya, and Yuko Tsujita. "The determinants of rural electrification: The case of Bihar, India." Energy Policy 39.6 (2011): 3086-3095.

[9] Central Electricity Authority, Growth of Electricity Sector in India from 1947-2019, May 2018. Retrieved 28 August 2019.

[10] Available online: https://powermin.nic.in/en/content/overview-1. [Access date15-10-2020]

[11] Central Electrical Authority, Draft on National Electricity Plan (2016), New Delhi,India.

[12] Ministry of Power, National Electricity Policy (2005), New Delhi, India.

[13] Dugoua, Eugenie, Ruinan Liu, and Johannes Urpelainen. "Geographic and socio-economic barriers to rural electrification: New evidence from Indian villages." Energy Policy 106 (2017): 278-287.

[14] Ministry of Law Justice and Company Affairs, The National Commission for Backward Classes Act, 1993, New Delhi, India.

[15] Robeyns, Ingrid. "Sen's capability approach and gender inequality: selecting relevant capabilities." Feminist economics 9.2-3 (2003): 61-92.

[16] Sovacool, Benjamin K., Roman V. Sidortsov, and Benjamin R. Jones. Energy security, equality and justice. Routledge, 2013. 
Journal of University of Shanghai for Science and Technology

ISSN: 1007-6735

[17] Nussbaum, Martha C. Women and human development: The capabilities approach. Vol. 3. Cambridge University Press, 2001.

[18] Sadath, Anver C. and Rajesh H. Acharya. "Assessing the extent and intensity of energy poverty using Multidimensional Energy Poverty Index: Empirical evidence from households in India." Energy Policy 102 (2017): 540-550.

[19] Minichiello, Victor, Rosalie Aroni and Terrence Neville Hays. In-depth interviewing: Principles, techniques, analysis. Pearson Education Australia, 2008.

[20] Kearns, Robin A. "Seeing with clarity: undertaking observational research." Qualitative research methods in human geography 3 (2010): 241-258.

\section{Appendix: Household survey}

$\begin{array}{ll}\text { Village: } & \text { Gram Panchayat: } \\ \text { District: } & \text { State: }\end{array}$

Respondent's Profile

\begin{tabular}{|l|l|l|}
\hline Name: & Gender: Male / Female & Age (Yrs.): \\
\hline Relationship with Head of Household: & Contact Number: & \\
\hline Identity Card: & Identity Card Number: \\
\hline
\end{tabular}

1. General Household Information

\begin{tabular}{|l|l|l|l|}
\hline Household No: & \multicolumn{2}{|l|}{ Name of the Head (Household): } & Male / Female \\
\hline Category: Gen / SC / ST / OBC/ EBC & \multicolumn{1}{|l|}{ Poverty Status: APL / BPL } \\
\hline Own House: Yes / No & $\begin{array}{l}\text { Type of House: Kutcha / } \\
\text { Semi Pucca / Pucca /Homeless }\end{array}$ & $\begin{array}{l}\text { Toilet: Private / Community } \\
\text { Open Defecation }\end{array}$ & $\begin{array}{l}\text { Drainage linked to House: } \\
\text { Covered / Open / None }\end{array}$ \\
\hline
\end{tabular}

\begin{tabular}{|c|c|c|c|c|c|c|}
\hline \multicolumn{7}{|c|}{ 2.Family Member Information } \\
\hline $\begin{array}{c}\text { Name } \\
\text { (Family } \\
\text { Members) }\end{array}$ & $\begin{array}{l}\text { Age } \\
\text { (Yrs.) }\end{array}$ & $\begin{array}{l}\text { Sex } \\
\mathrm{M} / \mathrm{F}\end{array}$ & $\begin{array}{l}\text { Marital } \\
\text { Status } \\
\text { Code }\end{array}$ & $\begin{array}{l}\text { Level of } \\
\text { Education } \\
\text { Code }\end{array}$ & $\begin{array}{l}\text { Computer } \\
\text { Literate } \\
\mathrm{Y} / \mathrm{N}\end{array}$ & $\begin{array}{c}\text { Major Health } \\
\text { Problems, if } \\
\text { any }\end{array}$ \\
\hline & & & & & & \\
\hline
\end{tabular}

\begin{tabular}{|c|l|l|}
\hline \multicolumn{3}{|c|}{ 5. Information of Government Schemes } \\
\hline $\begin{array}{c}\text { Sr. } \\
\text { No. }\end{array}$ & \multicolumn{1}{|c|}{ Name } & $\begin{array}{c}\text { Persons } \\
\text { Benefitted } \\
\text { (in Numbers) }\end{array}$ \\
\hline 1 & PM Jan Dhan Yojana & \\
\hline 2 & Soil Health Card & \\
\hline 3 & PM Awas Yojana & \\
\hline 4 & Sukanya Samridhi Yojana & \\
\hline 5 & Swachh Bharat MissionToilet & \\
\hline 6 & PM Jivan Jyoti Bima Yojana & \\
\hline 7 & PM Suraksha Bima Yojana & \\
\hline 8 & Fasal Bima Yojana & \\
\hline 9 & Atal pension Yojana & \\
\hline 10 & Kaushal Vikas Yojana & \\
\hline 11 & Krishi Sinchai Yojana & \\
\hline 12 & Jan Aushadi Yojana & \\
\hline 13 & Mudra Yojana & \\
\hline 14 & PM Ujjwala Yojana & \\
\hline
\end{tabular}

\begin{tabular}{|c|c|c|c|}
\hline \multicolumn{4}{|c|}{ 3.Source of Power and Water } \\
\hline \multicolumn{4}{|c|}{ Electricity Connection to Household/Farm: Yes / No } \\
\hline \multicolumn{4}{|c|}{ Electricity Availability per day (hours): } \\
\hline \multicolumn{4}{|c|}{ Lighting: Electricity / Solar Power /Batteries } \\
\hline \multicolumn{4}{|c|}{ Mention if Any Other: } \\
\hline $\begin{array}{l}\text { Sr. } \\
\text { No }\end{array}$ & Appliances & Nos & Duration in hours \\
\hline 1 & TV & & \\
\hline 2 & Ceiling Fan & & \\
\hline 3 & Radio & & \\
\hline 4 & Mobile & & \\
\hline 5 & Water Pump & & \\
\hline 6 & Tubelight & & \\
\hline
\end{tabular}

\begin{tabular}{|l|l|l|}
\hline 4. Source of Water & Distance \\
\hline Community Water Tap/Private & Yes / No & \\
\hline Hand Pump (Public / Private) & Yes / No & \\
\hline Well(Public / Private) & Yes / No & \\
\hline Any other source (mention) & \multicolumn{2}{|l}{} \\
\hline
\end{tabular}

\begin{tabular}{|l|l|l|}
\hline \multicolumn{2}{|l|}{ 6.Livestock Numbers } \\
\hline Cows: & Goats: & Buffalo: \\
\hline Bullocks: & Poultry: & \\
\hline Others (mention): \\
\hline Shelter for Livestock: Open /Pucca / Kutcha \\
\hline Production of Milk(Litres) daily: \\
\hline
\end{tabular}

Schedule Filled By (Name \&Sign):

Date of Survey:

Volume 22, Issue 12, December - 2020 